\title{
OBSERVATIONS OF REPTILES AND AMPHIBIANS, AND THOUGHTS ON CONSERVATION IN PRAIRIE CANADA
}

JOSEF K. SCHMUTZ, Prairie Ecosystem Sustainability Study (PECOS), Department of Biology, 112 Science Place, University of Saskatchewan, Saskatoon, SK S7N 5E2, and JUNE PICOTTE, 25 Sunflower Court. SE, Medicine Hat, AB T1B 2H6

The purpose of this article is to report incidental observations of reptiles and amphibians, and to place these in a human cultural context. Successful conservation strategies are deeply embedded in human beliefs and practices. The Canadian Biodiversity Strategy suggests that "...knowledge, innovations and practices of indigenous and local people should be respected."3

The northern Great Plains region supports few amphibians and reptiles, due to the dry and cold "continental" climate. Because of this rarity, pre-planned studies of these animals have been few. Incidental observations may be of value for assessing biodiversity. Species can be rare owing to their biological characteristics (e.g., some plants, top level predators), because they are declining, or because they are simply difficult to observe $^{11}$.

\section{Study area and Methods.}

Our observations in southeastern Alberta and southwestern Saskatchewan were derived from the memories and notes of June and Bill Picotte, memory and field notes of Joe Schmutz, and anecdotes reported to us by local people. June Picotte made her observations while she was growing up near Mendham, Saskatchewan in 1940-50, and later while she taught school in Bindloss, Alberta. She lived at the headquarters of the Remount community pasture south of Bindloss from 1959-90, near the northern edge of a large sand hill complex (Fig. 1). The pasture was used for grazing cattle during summer and early fall. This pasture was north of a $2500-\mathrm{km}^{2}$ military training area, Canadian Forces Base Suffield. Although parts of this region had been settled and used for farming in the early parts of this century, ${ }^{22,9}$ this region now includes grasslands as close to "natural" as any remaining on the Canadian prairies. Joe reports observations made during a study of raptors on a study area south and east of Hanna, Alberta, 1975-77 \& 1983-96 ${ }^{32}$. In addition, observations and conversations with landowners were recorded during a survey of 80 randomly selected study plots located throughout southeastern Alberta ${ }^{31}$.

\section{Snake sightings}

Based on our casual observations, snakes may have declined in southwestern Saskatchewan and southeastern Alberta. June recalls large, unidentified snakes (date not given; $E d$ ) with slate-blue and pink markings in a pasture and near a slough used by milk cows and horses, possibly a Red-sided Garter Snake (Thamnophis sirtalis parietalis). June and her siblings frequented this pasture often, enjoying abundant bird life and wild flowers. 


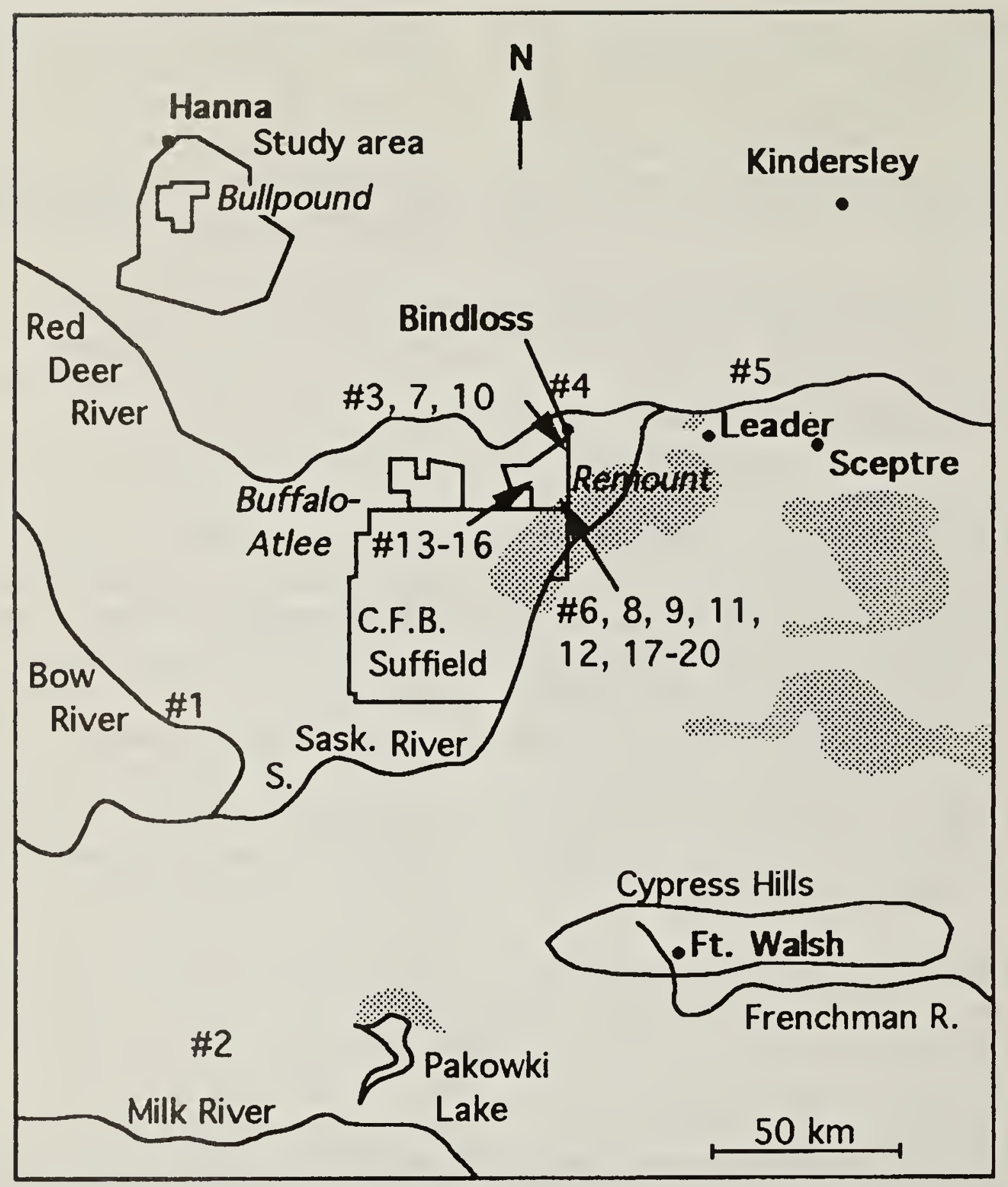

Figure 1. Locations of Buffalo-Atlee, Bullpound and Remount community pastures, administered by the Special areas Board of Hanna, Alberta. Stippled areas show sand hill complexes comprised of regosol soils. ${ }^{1,33}$

When teaching in Sceptre, Saskatchewan, in 1955, June and her grade I-II students examined a large garter snake, different in shape and color from the snakes of June's childhood. During the 1940s, she saw no small snakes and during the late 1940 s even the large snakes seemed rare.

Rattlesnakes. In 17 years of field work in the Hanna-Sunnynook area $25-50 \mathrm{~km}$ from the Red Deer River (Fig. 1), no rattlesnakes (Crotalus v. viridis) were observed. Similarly, local residents report- edly have never seen rattlesnakes there. This confirms the edge of the rattlesnakes distribution. ${ }^{38} \mathrm{~A}$ rattlesnake denning area (\#4) visited by Dan Wood and Frank Spath was on a ledge (250 $\mathrm{x}$ $50 \mathrm{~m}$ ) $40 \mathrm{~m}$ below the top of an eroded southeast facing tributary valley feeding southward into the Red Deer River canyon. Rattlesnakes basked on the ledge on warm days, at least in October 1990-92. On the ledge were over 100 rattlesnakes, approximately $25-120$ $\mathrm{cm}$ in length and up to 30 snakes per cluster. In former years garter and 
Bullsnakes (Pituophis melanoleucus sayi) were present also, but recently these may have moved to a hibernaculum nearby (Dan Wood and Frank Spath, pers. comm.).

Western Hognose Snake The Western Hognose Snake (Heterodon nasicus) is considered rare on the Canadian prairies. $^{42}$ In 1976, June saw her first of a total of 12 western hognose snakes (Table 1 \#6). It was unlike any snake she had seen before and a field guide confirmed its identification. This snake spread its head and hissed while observed. According to Plattwho studied hognose snakes in Kansas, the snake's stereotypical defensive behavior includes a threatening phase in which the head and front $1 / 3$ of the body are flattened and broadened ${ }^{26}$. The outspread scales reveal the brighter color of the interstitial skin. This can be accompanied by hissing, vibration of tail, concealment of the head under parts of body and "pseudo strikes" with mouth closed. If disturbance persists, death feigning sometimes ensues. Platt writes "When I picked up the western hognose snake, it began to hiss. I put it down and waved my hand at it. Each time my hand passed over it, it hissed and thrashed and coiled its body. It formed a round pancake coil with its head underneath and kept hissing. I kept touching it and it writhed and kept hissing. Finally, after approximately three minutes, it turned belly up, opened its mouth and quit hissing. It writhed for a few seconds. It then lay in a coil with its head on the inside, feigned death with its mouth partly open, and defecated."26

In spring 1977, June encountered another hognose snake (\#7) that hissed while being examined. The snake could not be induced to roll over or feign dead by tossing pebbles at it.

In July 1977, June encountered a

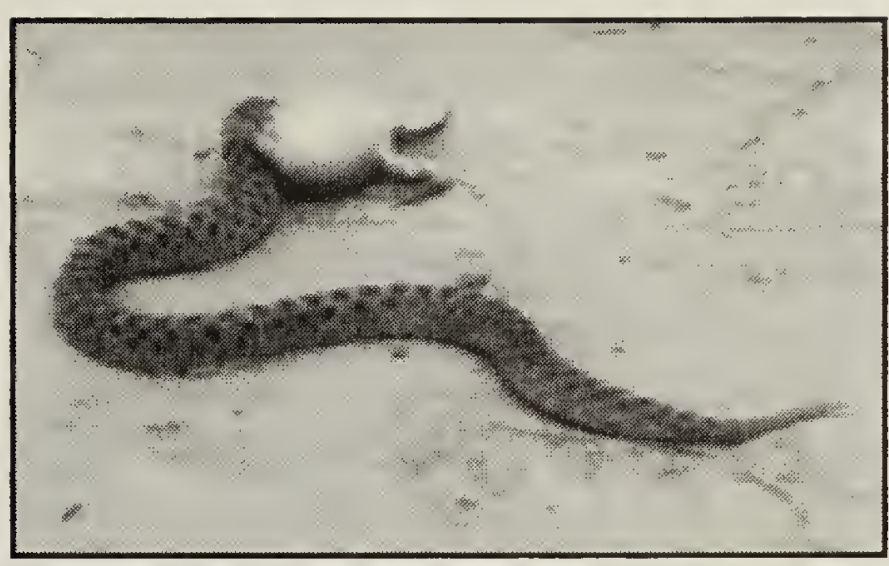

Figure 2. The photograph shows hognose snake \#8, attempting to swallow a toad.

hognose snake (\#8; Fig. 2). Judging from marks in the sand, the snake had apparently dislodged a buried toad (Bufo sp.). The toad had swelled considerably and was still alive. The snake was biting it or getting a better hold, and there was much blood. When gently prodded, the snake willingly abandoned its prey, expanded its head, hissed and then tried to escape. It did not feign death.

According to Platt, frogs and toads are a common prey of western hognose snakes, ranging from $26-36 \%$ of prey items ${ }^{26}$. The adaptations of hognose snakes for eating toads include expansive gape, enlarged rear maxillary teeth, and a physiological resistance to the poison produced by the skin glands of toads. ${ }^{26}$ Hognose snakes are apparently able to scent toads buried in sand. The snakes use their upturned nasal scale for digging toads out, or for digging escape burrows in sand.

In late August or early September 1983, June and a friend spotted a small hognose snake, about $50 \mathrm{~cm}$ long (\#10). The snake kept striking at June and her partner when disturbed.

Another hognose snake (\#11) did not have a good hold on a toad. Both were covered in sand from rolling. When separated from its prey, this snake also could not be induced to roll over or feign 
death. Other authors, as cited in Platt, were similarly unable to entice some western hognose snakes to feign death $^{26}$. In 1988, a hognose snake (\#13) with a toad in its mouth was on the roughly graded "fire guard" on the Remount pasture. A following vehicle ran over the snake accidentally.

While visiting areas in Alberta with a record of hognose snake sightings, Smith and Wershler, in 48-person days of searching, saw no hognose snakes ${ }^{34}$. Live traps with a $3.7 \mathrm{~m}$ barrier fence set for a total of 222.5 days in 1989 on the Remount Pasture and vicinity, captured one hognose (\#17). It appears that June may have seen more hognose snakes at the northern edge of the species' range in Alberta than most people. The 12 snakes which June and Bill have seen bring to 41 the total number of records known from Alberta since the $1920 s^{34}$ Pendlebury ${ }^{24}$. reported 14 records of Western Hognose Snakes from Alberta. All, except one disputed record near Craigmyle, were located in the extreme southeast of Alberta, from Empress southward.
Western Hognose Snakes tend to be largely active during the day, and hence poor visibility at night might not be a serious complicating factor in the rarity of observations. Leavesley found snakes in Manitoba active only on warm nights $^{19}$. Of 17 snakes monitored, their movements between 2-11 re-locations of the same individual ranged from 200 $700 \mathrm{~m}$.

Bullsnake The Bullsnake was noted around ranch headquarters for its predilection to climb. One Bullsnake had climbed a garage wall and was attempting to consume a nestling Barn Swallow (Hirundo rustica) tail first. Two additional snakes were on the ground as were the remaining nestling swallows that ha $d$ fluttered out of the nest. June took the three nestlings into the house until the snakes had left and these fledged successfully. On another occasion a large bull snake basked on the floor of a salt storage shed until evening. Judging from the silence of a normally noisy brood of common starlings (Sturnus vulgaris) inside the shed's double wall, these had been devoured

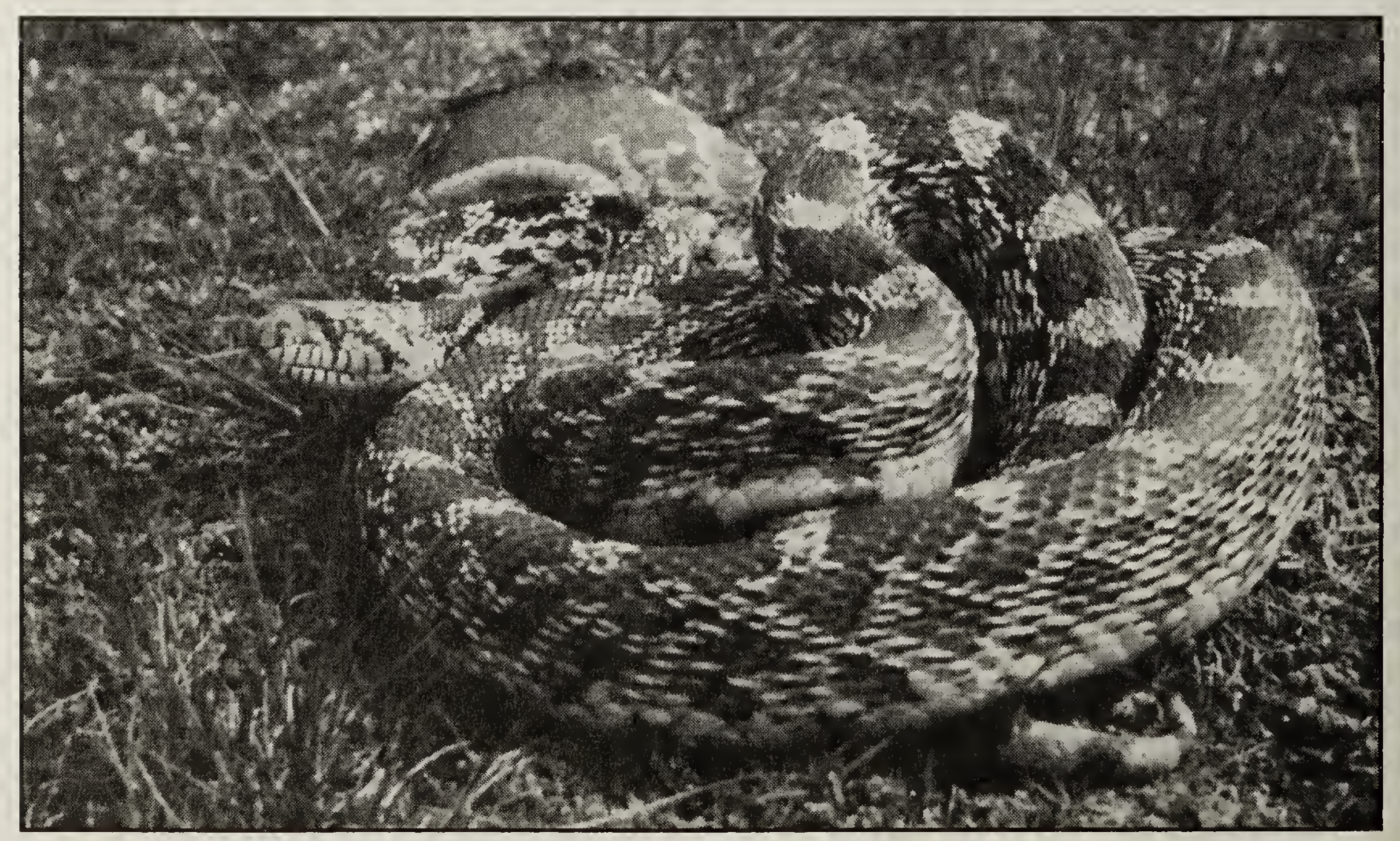


by the snake. A third sighting of a bull snake revealed an interesting antipredator behavior by a Nuttall's Cottontail (Sy/vilagus nuttallī), locally known as "bushrabbit." The rabbit leapt into the air repeatedly landing on a large bullsnake, presumably attempting to divert the snake away from a nest of young rabbits. As June and Bill moved closer to investigate, both snake and rabbit fled.

Yellowbelly racer Another rare snake, the Yellowbelly Racer (Coluber constrictor flaviventris), "may occur in Alberta south of the Milk River and east of Coutts." ${ }^{30}$ There are several recent reports of this species from southwestern Saskatchewan, including Grasslands National Park (Diane Secoy, pers. comm.). Dan and Gwen Wood (pers. comm.) observed an approximately 50 $\mathrm{cm}$ long Yellowbelly Racer $0.5 \mathrm{~km}$ west of Ft Walsh, Saskatchewan (Fig. 1), on 10 July 1993. Dan, who had hand caught many garter snakes before, could not catch this snake. It moved very quickly through grass. When encountering a dense stand of snowberry (Symphoricarpos occidentalis), it moved over top of the shrub's dense canopy and continued moving in the grass once on the other side. This snake was identical in appearance to the photograph of a racer taken by Lynch ${ }^{20: 109}$.

Unknown snakes On three different occasions, June saw snakes she could not identify. In July 1968, June encountered a dark gray or blue snake with a blunt head, about $80 \mathrm{~cm}$ long and moving slowly on a sandy road. In AprilMay 1971, while searching for arrowheads, June saw a $30 \mathrm{~cm}$ snake that reminded her of a "whipsnake" which she saw in a museum. In July 1972 or 1973 , one snake was nearly $1 \mathrm{~m}$ long, silver-gray, thin and moved unusually quickly in a friend's garden, where the friend had seen smaller versions of this snake earlier that year. Although these observations are not useful from a 'posivist' perspective, the observations do suggest that more surveys or screening of local knowledge could reveal a hidden biodiversity which is missed in surveys that are necessarily limited in scope.

Frogs and toads Over the years only one toad was seen near Hanna. In contrast, toads were common on the Remount Pasture. When the porch light was on at headquarters at night, toads (Great Plains Toads Bufo cognatus, or Dakota Toads $B$. hemiophrys) frequented the concrete step and with rapidly darting tongues caught insects attracted to the light. Also in contrast to Hanna, frequent observations of toads in a small regosol sandhill complex in aspen parkland near Joe's home west of Saskatoon further support the apparent association between sandy habitat and high toad numbers ${ }^{1}$.

\section{Biodiversity}

Changes in agriculture and their impact on biodiversity were as pervasive in June's youth as they are today. For instance, June's father sold the cattle the family owned in 1943 and began to grow only grain. This was the time when participation by farmers with the Canadian Wheat Board's policy for marketing grain became mandatory. Though some farmers benefited, this system was detrimental to nature conservation as a whole. Negative impacts of the Board's quota system on the prairie landscape included: encouraging excessive summer fallow, encouraging cultivation of marginal land, de-coupling marketing from the land's productivity, and disincentives that thwarted efficient production, diversification and forage production for livestock ${ }^{37}$.

Perhaps one of the most serious errors of the past was a singular, "broadcast 
type" of regional management style. Settlement, for instance, was advocated universally with little or no regard for soil type, for landscape, or rare features deserving protection. Many conservationists today feel that this mistake has been made and it is too late to change. Actually, prairie settlement by humans may be ongoing, proceeding in waves.

Perhaps the very first wave was settlement by aboriginal peoples after the glaciers retreated, then by explorers, trappers and "buffalo hunters," followed by ranchers and then farmers. The waves continued, homesteaders were replaced by mechanized agriculture, by industrial agriculture, chemical agriculture and most recently by diversification, biotechnology and corporatization in agriculture.

There is a need to consider in combination the diverse "capital" a nation has at its disposal: the capability of the land, the nature and aspirations of the people and the socioeconomic forces. These considerations are as urgent today as they were in the early days of prairie settlement. There are encouraging signs of more mature thinking today compared to the past, as reflected in the words ecosystem- or adaptive management. The future will tell how broadly and deeply these words and their actions are appropriated into our collective thinking.

\section{Attitudes and conservation}

Biodiversity conservation does not simply flow from a government building or from scientific literature, it requires the participation of people. This participation in turn is strongly influenced by what people believe or value. Human attitudes do not universally favor snakes. Joe has to force himself to overcome a deep seated fear of snakes. Snakes are frequent among roadkills (pers. obser- vations), and it is likely that many deaths are deliberate.

June's father knew about hognose snakes; local residents called them "puff adders." A story circulated about a person fishing near the South Saskatchewan River who fell asleep as a result of the puff adder's breath.

In June's youth, children were cautioned against and hence fearful of rattlesnakes. June herself grew up fearing rattlesnakes. When she married, her new home was at Bindloss in the Alberta sand hills (Fig. 1), an area well known for its many rattlesnakes. June feared for her two children but this fear was lessened when a neighbor reassured her that no child had ever been bitten by a rattlesnake in the Bindloss area (Fig. 1). As far as June knows, this still holds true today. This local knowledge about the danger of snakes, was likely much more influential than any policy or law could have been.

A horse, bitten on the nose by a rattlesnake, breathed with difficulty. Its head was swollen and green colored mucus oozing from the nostrils but it survived. The symptoms are consistent with the physiological effects of rattlesnake venom, including leakage of blood plasma and a lowering of breathing rate $^{8}$. The lethal capacity of the venom of the prairie rattlesnake ( $\underline{C} . \underline{v}$. viridis) ranks 20 th of 22 species/subspecies reported, behind the only other subspecies ( $\underline{C} . \underline{v}$. oreganus) that occurs in Canada (interior BC., 17 of $22^{8}$ ).

The effectiveness of any effort to protect snakes will depend on the degree of perceived or real danger to humans and livestock which rattlesnakes present. Even harmless snakes may suffer because people may be unwilling or unable to discriminate. A tolerance of, or even fondness for, rattle- 
snakes is not uncommon among farmers and ranchers who perceived that the snakes reduce rodent numbers. This component of local knowledge is clearly of immense value in snake conservation. This serves as an example of how local knowledge may be effectively built upon for conservation.

In conversation with landowners and lessees during a raptor survey in 1982, Jack Ross, residing south of the Milk River, reported that on one part of the ranch he commonly saw ground squirrels (Spermophilus sp.) but no snakes ${ }^{31}$. In the early 1980s, there were snakes but no ground squirrels. The rancher acknowledged that dog and stock suffered from an occasional bite, but even the cattle dog survived this. A farmer, north of the Milk River reflected that in eight years he had seen only two ground squirrels, and he attributed this to the presence of rattlesnakes. June has observed a rattlesnake swallowing a ground squirrel outside of a burrow (\#3, Table 1).

In some respects, biodiversity conservation on the prairies is another source for urban-rural conflict ${ }^{28}$. The problems Canada has encountered with the proposed endangered species legislation reflects at least in part a perceived and/ or real misalignment in public administration. The perception is that environmentalists armed with the power of science and government, are threatening a livelihood that has a tradition in Canada, albeit a short one ${ }^{40}$. Local land users may underestimate the urgency of protection for an ecosystem which they experience on a daily basis.

On 16 July 1997, the Biology Department, University of Saskatchewan received a call from a farmer near Eatonia. A rattlesnake had been seen on the driveway of a farm where children resided. The call was for advice on how to respond, what precautions to take and what treatment was called for in the case of a bite. Living with snakes, clearly requires a lifestyle adjustment. How does the environmental impact of a snake killed on the farm compare with the use of insecticides to kill mosquitoes in cities?

\section{Local and other forms of knowledge}

In 1963-64 a pipeline along the northern edge of the sand hills complex was added to an existing line built in 1958 . Work started about $6 \mathrm{~km}$ from ranch head quarters in May 1963. Snakes were moving then, north and west as they did each year, coming from their dens along the South Saskatchewan River. If the snakes fell into the pipeline trench they often hid under the pipe. To allay the workers' fears one employee was appointed snake killer. In one instance Bill Picotte counted eight dead snakes along a $1.6 \mathrm{~km}$ segment. During that summer and fall, ranch headquarters was "overrun" with mice. When children wandered in and out of the house without closing the door, mice came in. Bill Picotte hung his saddle from the roof of the barn to protect it from mice gnawing on the leather or building nests in the saddle bags. It was then that June came to appreciate rattlesnakes. To the people who lived in the area and knew snakes as predators of mice, the connection between snake deaths and the rodent outbreak seemed obvious, even if this apparent correlation did not necessarily reflect cause and effect.

The hognose snake observations of June and Bill are valuable in themselves given their rarity. According to the biological literature, mating and courtship of the hognose snake had not been observed until very recently ${ }^{27}$. On critical examination this statement may reflect an over-reliance on formally recorded "scientific" knowledge. It is pos- 
sible that this knowledge of mating was embedded in local knowledge long ago. It may be fruitful to find ways to encourage local knowledge to cross into the realm of formally recorded biological knowledge more frequently than is happening now ${ }^{16}$.

The Remount community pasture owes its existence in part to traditional knowledge. Jordan provides evidence to suggest that the open range herding of beef cattle originated first in the Eastern Hemisphere, was later prominently practiced on the Atlantic fringe of Europe and Africa, and moved from the Iberian peninsula to the New World ${ }^{15}$. Early mounted vaqueros used a spear to prod cattle and the use of rope with saddle horn may have been a New World innovation. Although the "openrange cattle-ranching strategy invariably caused habitat modification and damage, this was due to mismanagement and excessive grazing pressure (e.g., $\left.{ }^{7}\right)^{15}$. The grasslands of the Buffalo-Atlee and Remount community pastures, in contrast, have been maintained at a stocking rate of five and six animal unit months per acre ( $0.4 \mathrm{ha})$, respectively, during the summer months ( $\mathrm{cf}^{43}$ ). Range condition in both pastures was variable, ranked fair to excellent depending on distance to drinking water (Lorne Cole, pers. comm.). The diversity of range condition also leads to a diversity of animal consumers with some species occupying sparsely vegetated areas (e.g., Horned Larks Eremophila alpestris, deer mice Peromyscussp. and grasshoppers; and other species residing in moderately dense vegetation [e.g., voles] $)^{41,6}$.

Land users are frequently offended by the top-down and outside intervention they experience. Many incorporate in their own daily struggle their personal brand of conservation, encouraged by an ethical judgment that in turn is in- formed largely through local and traditional knowledge. This is rarely fully recognized, nor are many public administrators sufficiently educated in commumity psychology. For instance, spurred by a sense of protection Frank Spath was cautious when revealing the location of rattlesnake hibernacula. Bill Picotte, took a firm stance risking his position as pasture manager against calls to increase stocking rate on the Remount community pasture. A sense of protection for the grassland community that sustains them (e.g., ${ }^{5}$ ), is exhibited by many ranchers. This form of "social capital" may be as requisite for protection as the natural elements deemed threatened.

Given the widely acknowledged "biodiversity crisis' in prairie Canada and given the pressing question of whether the soil-life support system can be sustained throughout the prairies (e.g.,. ${ }^{2}$ ), it is urgent for biologists to help build solutions. The biological science agenda can have diverse goals that should be critically articulated for effective solution-building. Holton identified the "sociological setting" where conclusions are proposed for acceptance by other scientists ("invisible college" 44 ), and the "cultural setting" where goals respond to a society's needs ${ }^{13}$. Conservationists might be urged to step beyond the context of traditional disciplinary knowledge and appropriate other ways of knowing, consider the social context within which science operates, and become familiar with other forces in society (natural, economic and social capital; Fig. 3). Weeks and Packard concluded that holistic management in a ranching and fisheries setting was impeded by miscommunication between scientists and user groups, by an inability by resource users to built trust with agency personnel due to frequent change in personnel, and by an inappropriate re 


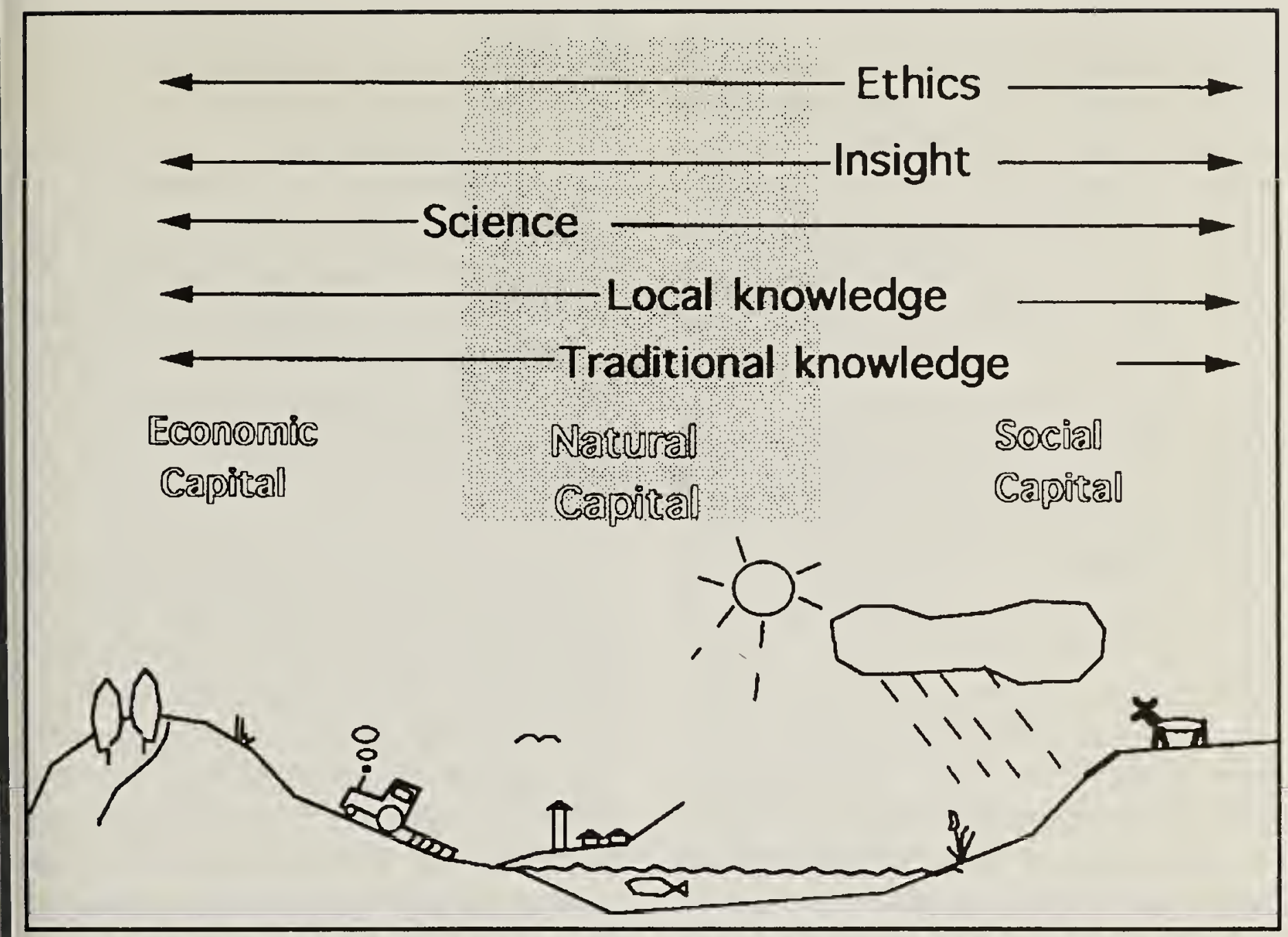

Figure 3. The conceptual diagram is intended to suggest that three types of resources or "capital" impinge on ecosystems in a co-evolutionary sense. For effective conservation, conservationists may need to become familiar with all three spheres, and appropriate diverse forms of knowledge beyond the substantive aspects of traditional biological science.

lationship between scientific and local knowledge ${ }^{39}$.

In our age of information overload and increasing specialization, it may be unrealistic for any one person to be equally well versed in economics and biology. Instead, a key solution may lie in cooperation and team work. For this to happen, dismantling the prevailing barriers between disciplines and reducing the chauvinism among types of knowledge may be an important first step.

\section{Protecting the snake's ecosystem}

Any coordinated attempt to conserve biodiversity will soon beg the perplexing questions of what manner of natural state deserves to be conserved (cf., ${ }^{14}$ ), over how large an area, and what conservation state is actually achievable in the long term ${ }^{29}$. Apparently, the highest level of protection and management can be achieved by most nations for only a small portion of the land. There are several difficulties associated with a static view of the "fortress" type of protection for an ecosystem alluded to here ${ }^{25}$. The grassland ecosystem owes its existence to a state of flux involving fire, and large and small grazers, whose ecology has been greatly altered. For meaningful protection for biodiversity and ecosystem health over areas large enough to entail functioning landscape-level processes, a ranching economy can be an important if not essential ally in prairie Canada. This is particularly true if this economy functions according to recognized range management principles, 
including: the balancing of animals and forage supply, approximating uniform livestock distribution, alternating grazing with rest, using livestock that suit forage supply and management objectives, and the recognition that physical factors, animals, and plants combined, act as an interdependent unit whose functioning can be disrupted ${ }^{43}$. An urgent need clearly still exists to protect with a "fortress strategy" particular features in small areas specifically for biodiversity and ecosystem health values. However, an appropriately managed traditional ranching economy can be importantly placed within a continuum of protection objectives: from the highest level of protection on small parcels of land to the moderate protection on a "working ranch" and finally to minimal protection in areas of industrial agriculture and other resource extraction. A traditional ranch can assist in the protection of "big space."

Two illustrations of a dilemma inherent in protecting portions of an ecosystem arose from the Middle Sand Hills, immediately south of the Remount community pasture (Fig. 1). In a quasi-natural state, feral horses roamed free in a military reserve. They degraded their favorite portions of the sand hill habitat so severely that they were removed (Gary Trottier, pers. comm.). In contrast, with continued management as in the past, the Remount pasture immediately to the North stands to serve ranchers and biodiversity conservation well. The Remount pasture is a "B-level" candidate for Alberta's Special Places ${ }^{4}$. However, it is unlikely that this small change in administrative status will affect the future of this "working ecosystem" significantly.

The value of the unique natural communities contained within the Canadian Forces Base Suffield, the Middle Sand Hills along the South Saskatchewan
River and the mixed grasslands to the southwest, has been recognized. An Order-in-Council, signed by the Ministers of the Department of Defense and the Department of Environment on 11 March 1992, designated joint management responsibilities for this 45,870 ha area. It also designates the affected lands as a National Wildlife Area in the event that the Department of Defense should relinquish ownership in the future.

In some respects, range management on the Remount pasture and parts of the Middle Sand Hills have allowed grasses to fare too well. At least two plant species considered threatened in Canada (Sand Verbena Abronia micrantha and the Western Spiderwort Tradescantia occidentalis) have lost habitat because active dunes have stabilized, apparently in response to "good" range management ${ }^{35,36}$. Wallis and Wershler $\left(\mathrm{in}^{35}\right.$ ) state that "Ironically, stabilization of active sand [in Nebraska] was seen as a good conservation practice. Land managers went to great lengths to stabilize active blowouts, extinguishing fires, modifying their grazing patterns and even placing old tires in the blowouts." It appears that a single-goal state for an ecosystem cannot be chosen easily from first principles. It may be fruitful to allow local conditions, local practices and traditional knowledge to help create some of the diversity which no doubt existed in the past.

\section{Conservation and production}

Some conservation action is achieved through spin-off benefit, such as the operation of a community pasture according to traditional and local knowledge. In addition, spin-offs arise from the personal/ethical compassion for a natural system whose "glory exceeds that of ours."12 Frank Spath and his family living close to so many dangerous 
snakes took an adjustment in lifestyle, a continual awareness and caution. Bill Picotte and Butala took some personal risks not so much to advance the cause of the hognose snake or Sprague's pipit (Anthus spragueii), but more likely because they felt that a portion of an ecosystem was "entrusted to their care." Greg Gordon (JKS pers. comm.) found the strip mining near his ranch, even with state of the art reclamation, an appalling intervention in a landscape. When confronted with the question of how an agricultural producer might balance economic losses with biodiversity values as in the case of his ranch, Francis Gardner (JKS pers. comm.) advanced, akin to "new age" deep ecologists, that a tolerance for "pest" species requires an appropriate connection to nature. This is relevant to ground squirrel management in Canada. These rodents are a "keystone species" on the one hand, and considered an agricultural pest on the other. Their survival locally depends on the tolerance by agricultural producers. Although a sensible word view is no absolute guarantee for socially and environmentally responsible action some world views are more promising than others ${ }^{10}$. How do such world views arise? How can they be influenced?

A regulatory mechanism for conservation is clearly required, in addition to individual stewardship. Economic instruments, when creatively applied as in a co-evolutionary, co-dependent sense, are additional avenues to enhance conservation ${ }^{18}$. In the case of the quota system (see above) the failure is reminiscent of single-capital (Fig. 3) administrative thinking. Recently, an opportunity may have been missed to rectify this, at least in part, through economic instruments. Following the cancellation of the "Crow Rate" transportation subsidies (c.f. ${ }^{17}$ ), a "payout" was made to landowners. This payout might have been tied to changes in practices that enhance sustainability and biodiversity. This illustrates another reason for the urgent need to not only consider different ways of knowing but also to bring together different disciplines with a systems perspective (e.g. $\left.{ }^{23}\right)$ toward administration.

\section{Acknowledgments}

We gratefully acknowledge the constructive comments provided on earlier versions of this manuscript by Andy $B$. Didiuk, Diane M. Secoy, Cliff Wallis and C. Stuart Houston.

\section{Literature Cited}

1. ACTON, D.F., G.A. PADBURY, and J.A. SHIELDS. 1992. Soil landscapes of Canada: Saskatchewan. Publication 5243/B, Contribution No. 87-45, Center for Land and Biological Resources Research, Agriculture Canada, Ottawa, ON. 1 map.

2. ANDERSON, DARWIN J., C.J. ROPPEL, and R.M. GRAY. 1991. Sustainability in Canadian agriculture. Science Council of Canada, Ottawa, ON.

3. ANONYMOUS. 1995a. Canadian biodiversity strategy: Canada's response to the Convention on Biological Diversity. Minister of Supply and Services Canada, Environment Canada, Ottawa. 77 pages.

4. ANONYMOUS. 1995b. Special places 2000: Alberta's natural heritage. Alberta Environmental Protection, Edmonton. 10 pages.

5. BUTALA, S. 1997. The Old Man on his Back Prairie and Heritage Conservation Area. Blue Jay 55:193-195.

6. CLAYTON, K.M. 1997. Post-fledging ecology of burrowing owls in Alberta and Saskatchewan: Their dispersal, 
survival, habitat use and diet. M.Sc. thesis, Dept. of Biology, Univ. of Saskatchewan, SK. 64 pages.

\section{FLEISCHNER, T.L. 1994. Ecologi-} cal costs of livestock grazing in western North America. Conservation Biology 8:629-644.

\section{GLENN, J.L., and R.C. STRAIGHT.} 1982. The rattlesnakes and their venom yield and lethal toxicity. Pp. 3-119 in A.T. $\mathrm{Tu}$ (Ed.), Rattlesnake venoms: Their actions and treatment. Marcel Dekker Inc., New York.

9. GORMAN, J. 1988. A land reclaimed: A story of the Special Areas of Alberta. Gorman and Gorman Ltd., Hanna, AB. 185 pages.

10. Hanson, L. 1995. Turning rivals into allies: understanding the wise use movement. Alternatives 21:26-31.

11. HARPER, J.L. 1981. The meaning of rarity. Pages 189-203 in H. Synge (Ed.), The biological aspects of rare plant conservation. John Wiley and Sons, New York.

12. HIGHLEY, B., and I. TYSON. 1991. Home on the range. Eastern Slopes Records, High River, AB.

13. HOLTON, G. 1978. The scientific imagination: Case studies. Cambridge University Press, New York. 382 pages.

14. HUNTER, M. Jr. 1996. Benchmarks for managing ecosystems: Are human activities natural. Conservation Biology 10:695-697.

15. JORDAN, T.G. 1993. North American cattle-ranching frontiers: Origins, diffusions and, differentiation. University of New Mexico Press, Albuquerque, NM. 439 pages.

16. JORDHEIM, S. 1997. The demise of the domestic gander. Blue Jay 55:204-206.

17. KLEIN, K.K., and W.A. KERR. 1996. The Crow Rate Issue: A Retrospective on the Contributions of the Agricultultural Economics Profession in Canada. Canadian Journal of Agricultural Economics 44:1-18.

18. VAN KOOTEN, G.C. 1993. Land resource economics and sustainable development. Univ. of British Columbia Press, Vancouver, BC.

19. LEAVESLEY, L.K. $1987 . \quad$ Natural history and thermal relations of the western hognose snake (Heterodon nasicus nasicus) in southwestern Manitoba. M.Sc. thesis, University of Manitoba, Winnipeg, MB.

20. LYNCH, W. 1984. Married to the wind. Whitecap Books, Vancouver, BC. 166 pages.

21. MACEWAN, G. 1986. Entrusted to my care: Safeguarding Canada's resources - our responsibility to the future. Western Producer Prairie Books, Saskatoon, SK.

22. MARTY, S. 1995. Leaning on the wind: Under the spell of the great Chinook. HarperCollins Publ. Ltd., Toronto. 317 pages.

23. NICHOLAS, J.M. 1990. Managing business and engineering projects: Concepts and implementation. Prentice-Hall, Englewood, NJ.

24. PENDLEBURY, G.B. 1976. The western hognose snake, Heterodon nasicus nasicus, in Alberta. Canadian Field-Naturalist 90:416-422.

25. PICKETT, S.T.A., V.T. PARKER, and P.L. FIEDLER. 1992. The new paradigms in ecology: Implications for con- 
servation biology above the species level. Pp. 65-88 in P.L. Fiedler and S.K. Jain, Eds. Conservation biology: The theory and practice of nature conservation, preservation and management. Chapman and Hall, New York. 507 pages.

26. PLATT, D.R. 1969. Natural history of the hognose snakes Heterodon platyrhinos and Heterodon nasicus. University of Kansas Publications, Museum of Natural History 18(4):253-420.

27. PLUMMER, M. V., and N.E. MILLS. 1996. Observations on trailing and mating behaviors in hognose snakes (Heterodon platirhinos). Journal of Herpetology 30:80-82.

28. ROWE, J.S. 1990. Home place. NeWest Publishers Ltd., Edmonton.

29. ROWE, J.S. 1997. The necessity of protecting ecoscapes. Global Biodiversity 7(2):9-12.

30. RUSSELL, A.P., and A.M. BAUER. 1993. The amphibians and reptiles of Alberta. University of Calgary Press, Calgary, Alberta.

31. SCHMUTZ, J.K. 1984. Ferruginous and Swainson's hawk abundance and distribution in relation to land use in southeastern Alberta. J. Wildl. Manage. 48: $1180-1187$.

32. SCHMUTZ, J. K., S.M. SCHMUTZ, and D.A. BOAG. 1980. Coexistence among three species of prairie hawks (Buteo spp.) in the prairie-parkland ecotone of southeastern Alberta. Can. J. Zool. 58:1075-1089.

33. SHIELDS, J.A., and J.D. LINDSAY. 1988. Soil landscapes of Canada: Alberta. Publication 5237/B, Contribution No. 8702, Land Resource Research Center, Agriculture Canada, Ottawa. 1 map.
34. SMITH, W., and C. WERSHLER. 1989. Pilot project on the study of the western hognose snake in Alberta. Unpublished report prepared for Alberta Forestry, Lands and Wildlife by Sweetgrass Consultants Ltd.

35. SMITH, B., and C. BRADLEY. 1990a. Status report on the sand verbena Abronia micrantha Torr. Prepared for the Committee on the Status of Endangered Wildlife in Canada, Ottawa, Canada, $36 \mathrm{pp}$.

36. SMITH, B., and C. BRADLEy. 1990b. Status report on the western spiderwort Tradescantia occidentalis (Britt.) Smyth. Prepared for the Committee on the Status of Endangered Wildlife in Canada, $65 \mathrm{pp}$.

37. THORNTON, F., J. BOWMAN and D. STRUTHERS. 1993. Agricultural policy review part 2: Wheat Board quota system. Blue Jay 51:65-71

38. WATSON, S. M. , and A. P. RUSSELL. 1997. Status of the Prairie Rattlesnake (Crotalus viridis viridis) in Alberta. Alberta Environmental Protection, Wildlife Management Division, Alberta Wildlife Status Report No. 6, Edmonton, $\mathrm{AB}$.

39. WEEKS, P. and J. M. PACKARD. 1997. Acceptance of scientific management by natural resource dependent communities. Conservation Biology 11:236-245.

40. WESTERN STOCK GROWERS' ASSOCIATION. 1995. Western Stock Growers' Association response to "A national approach to endangered species conservation in Canada." Calgary, AB. 24 manuscript pages.

41. WILSON, S.D., and J.W. BELCHER. 1989. Plant and bird communities of native prairie and introduced Eurasian 
vegetation in Manitoba, Canada. Conservation Biology 3: 39-44.

42. WRIGHT, J. 1998. Status of the Plains Hognose Snake (Heterodon nasicus nasicus) in Alberta. Alberta Environmental Protection, Wildlife Management Division, and Alberta Conservation Association, Wildlife Status Report No. 15, Edmonton, AB.
43. WROE, R.A., S. SMOLIAK, B.W. ADAMS, W.D. WILMS, and M. L. ANDERSON. 1988. Guide to range condition and stocking rates for Alberta grasslands, Alberta Agriculture, Lacombe, Alberta. 33 pages.

44. ZIMAN, J. 1984. An introduction to science studies. Cambridge University Press, New York. 203 pages.

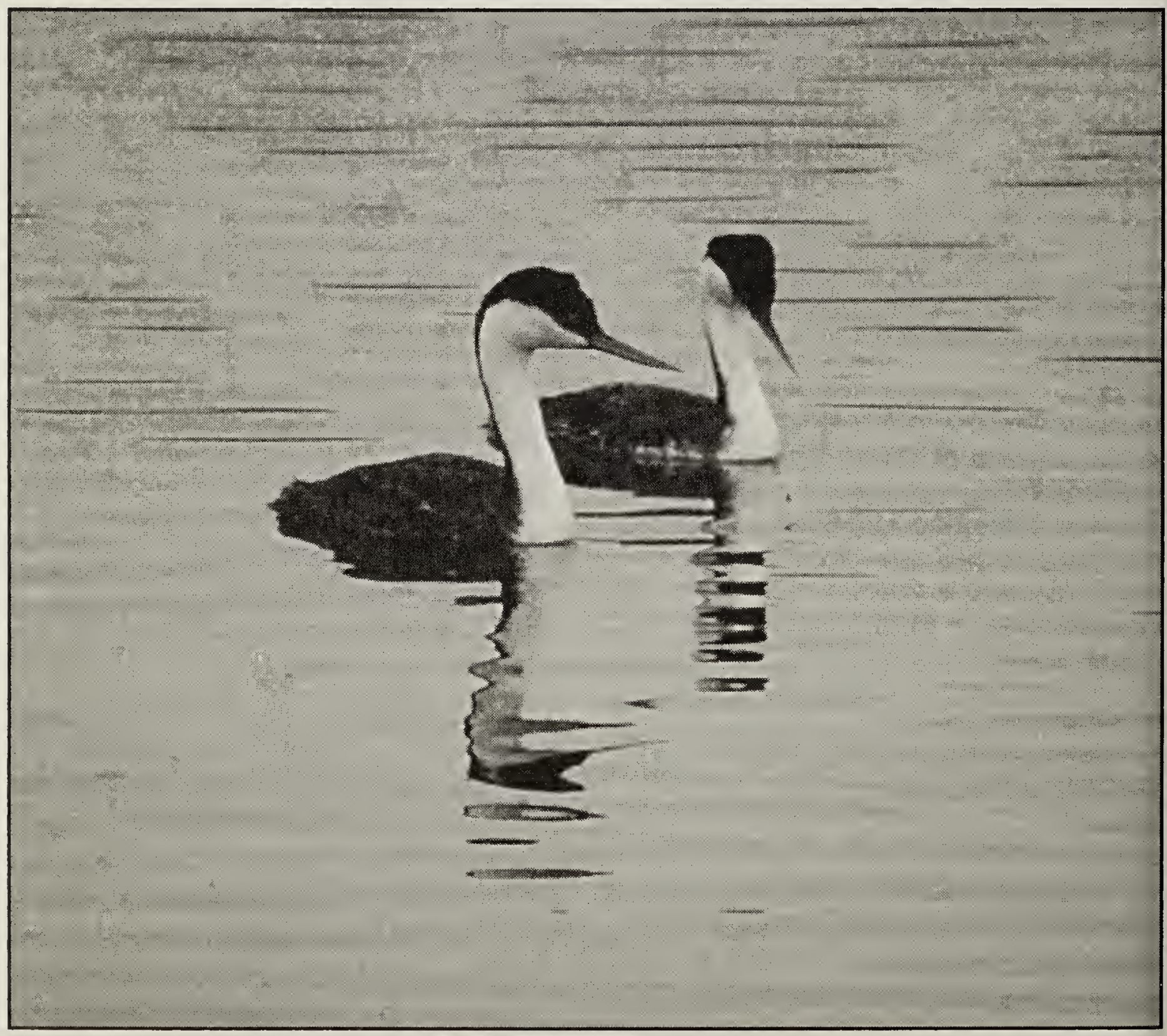

